\title{
The Uttilization of Jogja Smart Service Application: An E- Readiness Approach
}

\author{
Auliya Try Anggraini ${ }^{1}$, Muhammad Iqbal ${ }^{2}$ \\ ${ }^{1}$ Universitas Gadjah Mada, Daerah Istimewa Yogyakarta, Indonesia \\ ${ }^{2}$ Uiversitas Muhammadiyah Yogyakarta, Yogyakarta, Indonesia \\ Corresponding Author: auliya.try.a@mail.ugm.ac.id \\ Article Info
}

Keyword:
Smart City;
E-Government;
E-Readiness;
Jogja Smart Service

\section{Kata Kunci:}

Kota Pintar;

E-Government;

E-Readiness;

Jogja Smart Service
Abstract: This study will analyze the readiness of the Yogyakarta City Government in Jogja Smart Service services. This study will use the E-Readiness approach to measure government preparedness. The four indicators of the EReadiness model are Policy, infrastructure, financial resources and human resources. This research uses a qualitative approach. The findings show the Yogyakarta City Information and Bath Communication Office is ready in the implementation process in developing the concept of the smart city through the Jogja Smart service application. Policy readiness can be seen from the availability of the legal basis stated in Yogyakarta Mayor Regulation No. 15 of 2015 concerning e-Government and the decision of the mayor of Yogyakarta number 373 regarding the application of Jogja smart services related to the position, duties and functions of technical managers. From the aspect of the development of Jogja Smart Service application infrastructure, it is ready to implement the application of Jogja smart service. It is intended that the infrastructure has been available from previous years. Overall readiness of musty budget resources can be seen from a very significant budget allocation from year to year where the application of these funds comes from the budget, and there is no allocation of funds from the private sector. If viewed from the aspect of internal human resources, there is still a lack of human resources in the field of programmers so that the government cooperates with programmers in developing Jogja Smart Service applications.

Abstrak: Studi ini akan menganalisis kesiapan Pemerintah Kota Yogyakarta dalam pelayanan Jogja Smart Service. Studi ini akan menggunakan pendekatan EReadness untuk mengukur kesiapan pemerintah. Adapun keempat indikator model E-Readness adalah Kebijakan, infrastruktr, sumber daya finansial dan sumberdaya manusia. Penelitian ini menggunakan pendekatan kualitatif. Temuan menunjukkan Dinas Komunikasi Informasi dan Persandian Kota Yogyakarta telah siap dalam proses implementasi dalam mengembangkan konsep smart city melalui aplikasi Jogja Smart service. Kesiapan dari segi kebijakan terlihat dari ketersediaan landasan hukum yang tertera dalam Peraturan Walikota Yogyakarta Nomor 15 Tahun 2015 tentang e-Government dan keputusan walikota yogyakarta nomor 373 tentang penerapan jogja smart service terkait dengan kedudukan, tugas dan fungsi dari pengelola teknis. dari aspek pembanguanan infrastruktur aplikasi Jogja Smart Service sudah siap dalam melaksanakan penerapan aplikasi jogja smart service. Hal ini ditujukan bahwa 
infrastruktur tersbut sudah tersedia dari tahun-tahun sebelumnya. Secara keseluruhan Kesiapan dari apek sumber daya anggaran dapat terlihat dari alokasi anggaran yang sangat signifikan dari tahun ke tahun dimana aplikasi dana tersebut berasal dari APBD dan tidak ada dana alokasi dari pihak swasta. Jika ditinjau dari aspek sumber daya manusia internal masih kurangnya sdm dalam bidang programmer sehingga pemerintah melakukan kerja sama kepada ahli programer dalam mengembangkan aplikasi JOGJA SMART SERVICE.

Article History： Received: 2020-04-17, Revised: 2020-06-26, Accepted: 2020-06-29

\section{INTRODUCTION}

The development of urban development in the world has experienced a revolution caused by the development of information communication technology (ICT) (Mantikayan \& Abdulgani, 2017; Olaolu Micheal, Agwu Ekwe, Ivande Pauline, \& Olaolu Tochukwu, 2018). In its construction, the city became an attractive area for everyone. Cities have a dynamic of rapid change, in many predictions based on research results that almost $50 \%$ of the world's population will throng cities as residential areas (Hans, Sopu, Chisaki, \& Usagawa, 2016). Problems that occur in cities include difficulties in waste management, scarcity of resources, air pollution, human health problems, traffic congestion, inadequate roads, heavily damaged infrastructure. As a result, the city is increasingly facing enormous and complex challenges related to the facilities provided to its citizens (Liu, 2018).

Along with the rapid development of technology and the global environment is an inevitable phenomenon. This phenomenon also requires each country to adapt to become an underdeveloped party (Ahmed, As-Saber, Fry, \& Smith, 2018). The presence of technological and information developments has changed the way the interaction between government and society (Brooks, 2016; Ghosh Roy \& Upadhyay, 2017). According to (Alghamdi, Goodwin, \& Rampersad, 2016) that the use of information and communication technology influences public sector organizations to shift the culture and activities of organizations that were formerly manual or traditional and then turned into technology-based organizational activities (Alghamdi et al., 2016).

ICT-based public services are one of the implementations of the concept of the smart city, which is a concept of city and district management by emphasizing the use of ICT (AlSayegh, Hossan, \& Slade, 2019; H. Zaied, Hanafy Ali, \& El-Ghareeb, 2017). The provision of ICT-based information is integrated and makes it easy for users of information so that public services can be more effective and efficient and well-targeted (Chipembele \& Bwalya, 2016; D \& Ojetunde, 2019; Mantikayan \& Abdulgani, 2017). The government is the main actor in the provision of ICTbased public services, especially in terms of providing information. Utilization of information technology in local governments can improve the function and management of cities; one of them is e-government (Đurek \& Ređep, 2016; Fesenko \& Fesenko, 2016).

Research related to e-readiness has been carried out at the state level, private organizations, communities and employees (Ghosh Roy \& Upadhyay, 2017; Kasravi, Ahmadinia, \& Rezaiee, 2017; Sigwejo \& Pather, 2016). Dukic, et.al (2016) who examined the level of egovernment readiness of government employees in Croatia, which focused on ICT literacy competencies and standards. (Zhang, Asano, \& Yoshikawa, 2016) who examined the readiness of e-government from the perspective of state development with a focus on research related to the readiness of local interests and collaboration among actors in providing services to the government using strategic indicators, systems and data. Besides (Chipembele \& Bwalya, 2016) in his research that focuses on assessing e-readiness by evaluating e-government websites using 4 (four) e-readiness indexes. A previous study by (Kiula, Waiganjo, \& Kihoro, 2017) regarding the analysis of citizen e-readiness in the development of information technology-based villages, namely evaluating and measuring the readiness of the community's ability and concern for the village community towards (IT). The results showed that there was a sufficient level of ereadiness in the HR, culture and business climate factors when compared to e-readiness in the infrastructure and revenue factors. Other research in (Kumar \& Gupta, 2017) that measures people's readiness as public service users according to the M-Government system model. The 
findings study are the community are ready to participate in the implementation and change the system towards M-government. However, the availability of tools in implementing the $\mathrm{M}$ Government service system is not prepared because the community does not yet have a smartphone (Nento, Nugroho, \& Selo, 2017).

Evaluation of e-readiness has evolved and has various models. The models above use different definitions and measurement models. In this study, researchers will use the e-readiness model approach developed by (Kumar \& Gupta, 2017), where previous researchers tend to focus more on technology acceptance to the community, ICT readiness and local interests. Besides, an organization as a manager of an e-government system is also crucial in determining the success of e-government. Some indicators used to measure e-readiness in organizations are: 1) Policies 2) infrastructure 3) resources: budget resources and human resources.

Indonesia, as one of those that have implemented e-government. The legal umbrella that underlies e-government is stipulated in Presidential Instruction of the Republic of Indonesia Number 3 of 2003 concerning National Policies and Strategies for E-Government Development. Through the process of transformation towards e-government, the government is expected to optimize the use of information technology advancements to eliminate bureaucratic organizational barriers and form a network of management systems and work processes that enable government agencies to work in an integrated manner to simplify access to all information and public service. The e-government and Smart City ranking is considered one of the ten e-government development trends (Dwi putri, 2018).

Yogyakarta, as one of the major cities in Indonesia, is one of the towns that applies the concept of a smart city. The efforts provided by Yogyakarta regional government for the welfare of the community, one of which is to use technology and information. Based on, PeGi (Indonesian e-government ranking) at the Regency / City level in Banten, DIY, Bali, NTB, Kalimantan, Sulawesi in 2015, that the Yogyakarta City Government's e-government system succeeded in ranking first (Nento et al., 2017).

To welcome the implementation of e-government, the Government of Yogyakarta City issued a Mayor Regulation Number 15 of 2015 which contained a roadmap for e-government development within the scope of the City of Yogyakarta. In the planning contained in Mayor Regulation No. 15 includes several stages, including:

a. Strengthening network infrastructure

b. Strengthening information system infrastructure

c. Data integrity and application development

d. Data warehouse

e. Policy towards Smart City.

In 2018 Yogyakarta was chosen as one of the cities that will carry out the Movement Towards 100 Smart Cities program with 24 other Regencies or Cities in Indonesia. In the 20172022 RPJMD. Yogyakarta City has a concept of a smart city that refers to innovations in the field of information technology to provide benefits and ease of service to the community. Based on the issuance of Mayor Regulation No. 15, the Yogyakarta city government rolled out applications that can be accessed by the public in supporting the implementation of smart city and e-government named Jogja Smart Services. Quoting from (Republika.co.id 11 June 2018) the Jogja Smart Services application made by the Yogyakarta Informatics and Bath Communications Office is the development of the complaint service that has been owned by the Yogyakarta City Government since 2003. This JOGJA SMART SERVICE (Jogja Smart Service) application can be downloaded via the Play Store found on the Android operating system.

The presence of the Jogja smart service application that brings together a variety of public services in the one-door concept, one of which is that people are more comfortable and more practical in submitting complaints, requesting permits, and emergencies. Based on the explanation above, this research needs to be done considering that research related to the readiness of a government organization and the factors that influence the intentions of the community as recipients and the use in adopting new technology is still little done by academics. Where the two components are crucial in seeing the successful implementation of e-government. 
So, this study will use the e-readiness approach to know the readiness of the Yogyakarta city government in applying e-government, namely: Jogja smart service application.

\section{RESEARCH METHOD}

This research is descriptive qualitative research, which is conducted to describe the problem being studied and objectively integrate the data in the research location. Qualitative research methods are a series of research procedures that produce descriptive data in the form of words both written and oral about the nature of individuals, situations, symptoms of groups or even specific groups that are being observed (Moleong, 1994). Researchers choose to use this method because it is very suitable to be used in the process of finding data to answer existing problems and support research needs. The type of data used in this study is primary data obtained from interviews with relevant stakeholders such as Jogja Smart Service Managers at the Yogyakarta Office of Communication, Information and Baths. Besides, this research also uses secondary data obtained from literature study results, written sources from various websites and related government social media, as well as news and documentation that can support and complete research analysis materials.

\section{Policy}

\section{RESULT AND DICUSSION}

As the rapid development of urban areas makes the problems that occur in several large cities, especially the city of Yogyakarta, it becomes increasingly complex. In solving this problem, the city of Yogyakarta applies the Smart City concept, which is a solution and provides benefits and ease of service to the public as well as the intellectual life of the nation. Besides, the realization of a smart city is in line with the goals of sustainable development or Sustainable Development Goals were to support this, a good political will, legal basis and strategy are needed.

The legal basis that underlies the establishment of the Jogja Smart Service application to welcome the implementation of e-government that previously, the city of Yogyakarta issued a Mayor Regulation No. 15 of 2015 which contained a roadmap for e-government development within the scope of the City of Yogyakarta. Planning as stipulated in Mayor Regulation Number 15 of 2015 includes several stages including a) Strengthening network infrastructure b) Strengthening information system infrastructure c) Data integration and application development d) Data warehouse e) Policy towards Smart City.

Furthermore, based on the issuance of Mayor Regulation No. 15 of 2015 the Yogyakarta city government began rolling out applications that can be accessed by android users to support the implementation of smart city and e-government called Jogja Smart Services. As stipulated in the decision of the mayor of Yogyakarta number 373 regarding the application of Jogja smart services related to the position, duties and functions of the technical manager. According to Mrs Ian in the field of Public Communication in addition to the decision of the mayor which underlies the running of the Jogja smart service program, the Yogyakarta City Government then issued Mayor Regulation Number 33 of 2018 concerning electronic-based urban and sub-district services. As a legal basis for providing services both at the village and sub-district levels online that can be accessed by the public through the Jogja Smart Service application. The scope of service delivery in the villages and sub-districts of electronic distribution includes licensing and non-licensing services.

In planning the smart city of Yogyakarta, of course, it has gone through a series of planning processes as the City of Yogyakarta entered into the movement of 100 smart cities and was asked to draw up a master plan. The master plan was made to answer the problems in each region so that this master plan can be a reference for building smart concepts in the city of Yogyakarta.

Starting with the preparation of the 2015-2019 roadmap for the development of egovernment carried out by the development planning Agency (Bappeda) in 2014. The Yogyakarta Smart City Road Map is integrated into the Yogyakarta City RPJMD to be 
prepared, so that policies, strategies, objectives, targets, as well as programs covered by the Yogyakarta City planing. Furthermore, Yogyakarta Smart City initiatives and initiatives can be accommodated in the preparation of the Yogyakarta City planing and related Local Government Organization Strategic Plans. The next step is to establish innovative programs which are packaged in quick wins, one of them is the Jogja Smart Service, which is the leading portal of the city of Yogyakarta, which is made by the Yogyakarta Information and Bath Communication Office. Jogja Smart Service provides integrated services related to services, administration, data and information online through applications with the concept of single ID, single sign-on and unique windows.

From the above statement in the 2017-2022 RPJMD, Yogyakarta City has a concept of a smart city that refers to innovations in the field of technology, the information to provide benefits and convenience in service to the community. Yogyakarta City Smart City was agreed with the term Jogja Smart Service. In this regard, the Mayor has appointed the Smart City Board and Implementation Team to prepare and implement the Yogyakarta City Smart City Master Plan and to establish the Yogyakarta City Information and Communication Communication Office as a leader in the work program following the mandate of the Planing (Kominfo Kota Yogyakarta, 2018). Besides, the Smart City of Yogyakarta city can be realized because of the consolidation of several parties that have namely academic, business and Government. In carrying out the study of Yogyakarta smart city, has involved the A-B-G. The function of the smart city council, as a leader or 'conductor' in running the Yogyakarta smart city program. This smart city council is comprehensive or blended as coordination of overall development in the sense of not only providing applications but also providing knowledge/education. The thing that must be underlined is that the smart city road map is flexible and involves external factors such as technology, which means that changes can be made in the coming years in line with the times and technology.

Furthermore, in addition to several Mayor Regulations number 373 regarding the application of Jogja Smart Service, there is also a standard operating procedure (SOP) for Jogja Smart Service, which is an internal guideline or reference for implementing the Jogja Smart Service implementation process. The SOPs contained in mayor regulation number 373 consist of:

1) SOP for handling emergencies

2) SOP for handling complaints

3) SOP of general services

4) SOP of requests or requests for data and information

Jogja Smart Service SOP is a mechanism of the stages of work in the administration and coordination of the implementation of the Jogja Smart Service in the Yogyakarta City Government. The Jogja Smart Service standard operating procedure (SOP) is practically written in the form of a document contained in the decision of the mayor of Yogyakarta number 431 of 2018 concerning the establishment of operational standards for the Jogja smart service procedure in the Yogyakarta city government. Furthermore, SOP is also a procedural guideline that must be understood by all relevant stakeholders, because this Jogja Smart Service service is an integrated service in various Local Government Organizations from the government, sub-district and village level. Then in the Jogja Smart Service SOP, Each regional apparatus/work unit is required to follow up on every service request from the community following their area of work which is guided by the Standard Operating Procedures respectively to follow up on complaints or incoming claims with a maximum of 2 hours given to respond to the community.

\section{Infrastructure}

Another factor that determines a government organization is ready and successful in implementing a program is infrastructure development. According to Garlic (2011), information technology infrastructure is the necessary foundation of information technology capabilities. This information technology capability includes internal technical (equipment, software, and enabling) as well as human expertise needed to provide reliable 
services. Meanwhile, according to Bryd and Turner (2000) IT infrastructure is also interpreted as the central supporting infrastructure of technological resources consisting of basic physical techniques from hardware, software, communication technology, data, core applications and human components, namely special expertise, commitment, values, norms and knowledge combined to create information technology services that are unique to the organization. It can be said that information technology infrastructure is the most basic level of information technology components. Information technology infrastructure includes equipment, hardware, software, networks and people as supporting elements in it that are needed to provide reliable services. The readiness that has been carried out by the Yogyakarta municipal government in supporting smart cities in terms of information and communication technology infrastructure related to the Jogja Smart Service application program are:

"'Regarding the information technology infrastructure needed to create and develop Jogja Smart Service applications, including hardware, software, networks. For hardware, we have just upgraded where previously we used series 4 for Android. In August 2019, there was a new policy from Google that stated hardware standards for applications under version 4 could no longer be supported, so we did the upgrade by following the procedure. Then in each of our software, we develop data centres such as Optimizing security in server services (username, password, antivirus and operating system updates, firewalls, ports, monitoring systems, auto-lock, secure applications on servers and so on) "(Interviewing Mr Aan, 2019).

Based on the explanation above, to run a program based on the Yogyakarta city government application especially the information communication and coding service city of Yogyakarta, the development and strengthening of Information and Communication Technology Infrastructure as ICTs is an essential part in creating an integrated service system to support smart cities, especially Jogja Smart service applications.

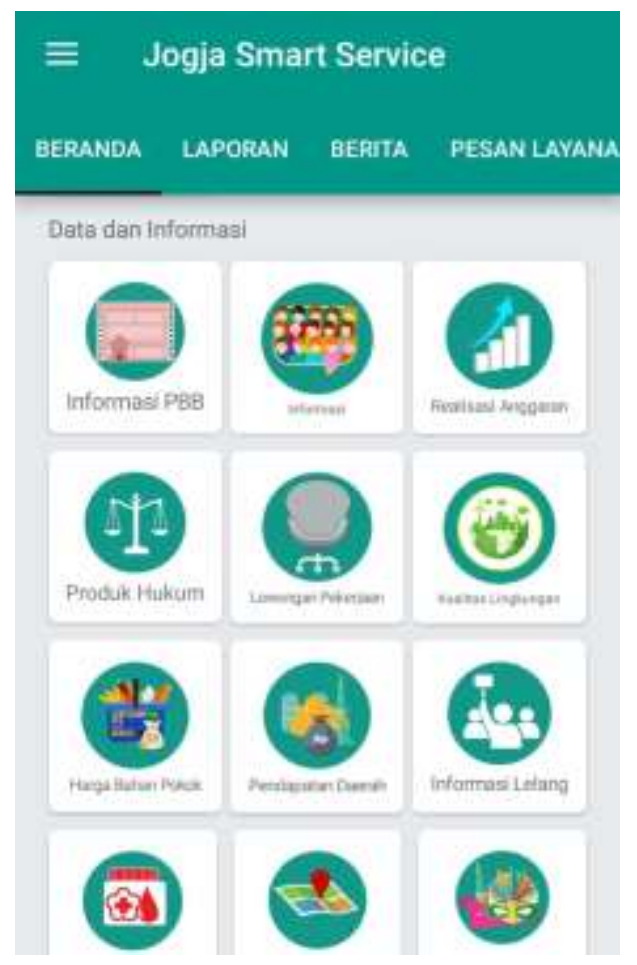

Figure.1

Jogja Smart Service

Sumber: jogjakota.go.id 
Furthermore, efforts that have been made by the Yogyakarta municipal government include the strategy of developing information and communication technology infrastructure that has been prepared as a policy direction and guidance in the form of Yogyakarta mayor regulation number 100 in 2018 About MasterPplan for the development of the smart city of Yogyakarta in order to obtain optimal results. Specifically the development of communication technology infrastructure that includes all technical equipment used to process and handle information and communication through a combination of computer technology to support the running of the Jogja Smart Service application program including development of data centres, hardware and software, servers, development of Fiber Optic Mandiri and network development supporters.

In addition to utilizing and developing communication and information technology infrastructure, the information and coding service department of the city of Yogyakarta needs to pay attention to the management of communication and information technology infrastructure in various ways to achieve the effectiveness of the entire IT process. Regarding the management of technology infrastructure, explained by Mr Aan in the field of information communication and coding services in Yogyakarta City.

"As for the management of communication and information technology infrastructure, we carry out routine checking maintenance depending on the needs such as Ram when it is slow we immediately raise the Ram, change with, increase bandwidth, change of network, and hardware. As for the software, we check the database, the traffic. We have received reports from the population office and civil registration related to the system down, where the people of the city of Jogja were not integrated according to the NIK when logging in. So they can not use the services needed. Then after receiving information related to the obstacle, the Information and Communication Agency immediately checks and justifies the system. In addition to the many requests from the public to develop the Jogja Smart Service application to the Apple Store, the Ministry of Communication and Information has tried to submit a registration to be accessible to the Apple Store or based on iOS. However, until now, it is still constrained in terms of licensing (Interviewing Mr. Aan, 2019).

From the statement above, it can be said that there are obstacles that sometimes occur in the use of Jogja Smart Service applications. Starting from a down system, which makes people not integrated with NIK, it is their identity as a Jogja Smart Service application user. When viewed from the reviews contained in the Jogja Smart Service application, quite a lot of people review the server error and discussions related to the application that cannot be opened after upgrading. So it is crucial to pay attention, especially maintenance, regularly checking as needed. Furthermore, the Jogja City Government developed the Jogja Smart Service application by adding special access for Apple users due to the many recommendations made by the people of Yogyakarta for not just my Android that can access the Jogja Smart Service application. However, up to now, it has not been able to run in its implementation due to obstacles in the licensing process

\section{Financial Resources}

Another factor that determines a government organization is ready and successful in implementing a program is the availability of a budget to support the running or sustainability of the program implementation. The available budget resources can produce outputs from the implementation of the program better.

According to the results of an interview with Mr Joko, Head of Jogja Smart Service Development, it was found that related to the Jogja Smart Service program as a whole the budget came from the APBD. If referring to the Government Institutions Performance Report of the Yogyakarta City Communication and Information Technology Office, 2018 in achieving the 2018 work target, the informatics communication and coding department of the city of Yogyakarta are supported by the 2018 expenditure budget of Rp. 24,671,789,901, - includes: indirect spending Rp 2,876,689,431 and direct shopping Rp 21,795,097,470 with a comparison 
between indirect shopping and direct shopping $88.34 \%$ compared to 11.66 . More specifically, the absorption of direct expenditure budget Communication, Information and Coding in 2018 is greater in absorption than the 2017 budget of $94.81 \%$ of the total direct expenditure budget allocated. However, the absorption of that many members was not intended for the Jogja Smart Service special program, because for Yogyakarta information and coding communication affairs, there were a number of activities and programs in 2018. Based on interviews with Mr. Aan, the software sector said:

"Overall, the Jogja Smart Service Program budget from ABPD. However, there is no specific allocation for Jogja Smart Service because before there was Jogja Smart Service, we already had infrastructure development. The budget that is widely used is the budget for the application. There are also several Regional Organization that the system already exists, just to be integrated and combined into one. One example is the market levy service where this feature was built from scratch, for applications only around Rp. 45,000,000. then we are also assisted by the programmer in implementing this Jogja Smart Service with a monthly salary above starting from Rp. 3,000,000Rp5,600,000 "(Interview of Pak Aan, 2019)

The explanation above can be concluded that the budget allocation for the Jogja smart service program as a whole is from and ABPD. Indirectly, there is no grant from the private sector to develop the application. Furthermore, this study did not get detailed details about the budget allocation used in the Jogja Smart Service program. This is because as is the case with the development of existing infrastructure, for example, optical Viber that was formed in 2013 while the budget for information and communication technology infrastructure that covers the needs of the related Local Government Organization is the information communication and coding office of the city of Yogyakarta.

\section{Human Resources}

Human resources are essential resources in every organization, where humans are the movers and managers of other resources. Besides, human resources are one crucial factor in the implementation of a program in government. The success of public service transformation is very dependent on the knowledge, skills, motivation and willingness of human resources to accept change (Dukic, et.al 2016).

Based on data from the performance reports of government agencies as a whole the number of personnel of the Office of Communication, Information and coding up to December 2018 was 54 people consisting of 43 people with the status of Civil Servants (PNS) and 3 Personnel Staff (Naban) and eight technical staff (LKIP, 2018). Furthermore, in addition to employees in the information and coding communication services involved in the management of the Jogja Smart Service application, the Local Government Organization contributes and is integrated into the Jogja Smart Service application following their respective modules. The interview supports this Mr. Joko said:

"Regarding human resources in managing the Jogja Smart Service application, there is a communication and communication agency, but in the process of implementing every Local Government Organization that has modules and services in the Jogja Smart Service system, it is also involved. A team forms the Local Government Organization which has a module called the quick reaction team to respond to complaints and services through the Jogja Smart Service application, while for the sub-districts and village office-level a service section is formed which is the employee in charge of providing services online" (Interview with Mr. Joko, head of smart city development)

Here it can be seen that HR has an important role in implementing a program. Not only one or two parties involved, but each Local Government Organization who contributed and was integrated into the Jogja Smart Service system. As explained by Mr. Joko, the head of the smart city development sector, said that each team had formed an organization called the Rapid 
Reaction Team (TRC) before, so that there were operators tasked with responding to complaints and online services. Based on research that has been done, the Dissemination and Information Agency made efforts to improve the quality of employees. According to Mr. Aan, the software section was known to be in the initial stages of communication and information technology. This training is usually associated with knowledge related to ICTs, big data, skills training. Furthermore, this training plan is carried out approximately twice a year. The employee training is for the Local Government Organization, sub-district and village levels, such as technical guidance and instruction, understanding technical procedures and technical operations related to Jogja Smart Service applications.

With the training of Yogyakarta city administration level employees to schedule technical guidance before the application is launched. As for the Local Government Organization that has just been integrated into Jogja Smart Service such as the addition of the health module, the market levy module by the relevant Local Government Organization, it is usually requested to provide technical guidance to the HR. But it will be different from the above statement, as reported by the Jogja Tribune online media, that all the devices at each level of the institution receive technical guidance and training. For example, Pandeyan Umbulharjo Yogyakarta village said that the village were ready to support the Jogja Smart Service program, so the supporter needed technical and operational understanding of the application, especially to follow up on complaints and services accessed by the public that became the authority. From the findings above, there is still a lack of equitable and less structured socialization plan carried out at the beginning of the launch of the Jogja Smart ServicE application.

\section{CONCLUSION}

For the readiness of the aspects of developing Jogja Smart Service application infrastructure is ready to implement the application of Jogja smart service. It is intended that the infrastructure has been available from previous years. Because this Jogja Smart Service application is the development of a compliant service called UPIK, it's just that there are obstacles in the licensing process to develop IOS-based Jogja Smart Service applications.

Overall readiness of musty budget resources can be seen from a very significant budget allocation from year to year where the application of these funds comes from the budget, and there is no allocation of funds from the private sector. If viewed from the aspect of internal human resources, there is still a lack of human resources in the field of programmers so that the government cooperates with programmers in developing Jogja Smart Service applications. Whereas in the early stages of implementation, especially at the village level, there has not been an even distribution and the delay of several instruments at each level of the agency received training on understanding and operational, technical instructions such as the technical followup that is under the jurisdiction of the region, but this has been handled by the information communication department and Yogyakarta city coding.

\section{REFERENCE}

Ahmed, F., As-Saber, S., Fry, S., \& Smith, R. (2018). Bureaucracy and E-government: A study of eprocurement initiatives in Bangladesh. Journal of Business Management \& Compliance, I(1), 35-51. Retrieved from http://osderpublications.com/uploads/1516180161.pdf

Alghamdi, I. A., Goodwin, R., \& Rampersad, G. (2016). Ready, set, govern: Readiness of Saudi Arabian organizations for e-Government. International Journal of Electronic Government Research, 12(1), 69-98. https://doi.org/10.4018/IJEGR.2016010104

AlSayegh, A., Hossan, C., \& Slade, B. (2019). Radical improvement of e-government services in Dubai. International Journal of Services, Technology and Management, 25(1), 53-67. https://doi.org/10.1504/IJSTM.2019.096613

Brooks, T. (2016). Information Society Evolution and Effects.

Chipembele, M., \& Bwalya, K. J. (2016). Assessing e-readiness of the Copperbelt University, Zambia: case study. International Journal of Information and Learning Technology, 33(5), 315-332. https://doi.org/10.1108/IJILT-12-2015-0036

D, A. A. P., \& Ojetunde, S. M. (2019). Comparative Analysis of Networking and E-Readiness of Some 
African and Developed Countries Comparative Analysis of Networking and E-Readiness of Some African and Developed Countries International Center for Educational Evaluation ,. (November).

Đurek, V., \& Ređep, N. B. (2016). Review on e-readiness assessment tools. Central European Conference on Information and Intelligent Systems, 161-169.

Dwi putri, N. aslamaturrahmah. (2018). E-Readiness Provinsi Kepulauan Riau dalam Penerapan E-Government (Studi Terhadap Kepri Smart Province). Kemudi, 3(1), 173-192.

Fesenko, T., \& Fesenko, G. (2016). E-readiness evaluation modelling for monitoring the national e-government programme (by the example of Ukraine). Eastern-European Journal of Enterprise Technologies, 3(3-81), 28-35. https://doi.org/10.15587/17294061.2016.71606

Ghosh Roy, S., \& Upadhyay, P. (2017). Does e-readiness of citizens ensure better adoption of government's digital initiatives? A case based study. Journal of Enterprise Information Management, 30(1), 65-81. https://doi.org/10.1108/JEIM-01-2016-0001

H. Zaied, A. N., Hanafy Ali, A., \& El-Ghareeb, H. A. (2017). E-government Adoption in Egypt: Analysis, Challenges and Prospects. International Journal of Engineering Trends and Technology, 52(2), 70-79. https://doi.org/10.14445/22315381/ijett-v52p212

Hans, T., Sopu, Chisaki, Y., \& Usagawa, T. (2016). Use of facebook by secondary school students at Nuku'alofa as an indicator of E-readiness for E-learning in the Kingdom of Tonga. International Review of Research in Open and Distance Learning, 17(4), 203-223. https://doi.org/10.19173/irrodl.v17i4.2333

Kasravi, M. S. M., Ahmadinia, M., \& Rezaiee, A. (2017). A Multi-layer Architecture Based on MCDM Methods to Select the Best E-Readiness Assessment Model According to SWOT Analysis. Journal of Advances in Computer Engineering and Technology VO - 3, 3(2), 65. Retrieved from http://search.ebscohost.com/login.aspx?direct=true\&db=edsdoj\&AN=edsdoj.137eb76316 a24b789b3291198dad35f9\&site=eds-live

Kiula, M., Waiganjo, E., \& Kihoro, J. (2017). Novel E-Readiness Accession in Higher Education Institutions in Kenya. International Journal of Managerial Studies and Research, 5(6), 101111. https://doi.org/10.20431/2349-0349.0506014

Kumar, S., \& Gupta, S. K. (2017). E-Readiness: a state of preparedness to participate in the digital economy. AgricINTERNATIONAL, 4(2), 42. https://doi.org/10.5958/24548634.2017.00023.7

Liu, L. (2018). The Barriers of Local E-Government in China??qA Case Study. Advances in Computer Science Research, Volume 83 8th International Conference on Social Network, Communication and Education (SNCE 2018), 83(Snce), 619-624. https://doi.org/10.2991/snce-18.2018.126

Mantikayan, J. M., \& Abdulgani, Mo. A. (2017). Conceptualizing E-government Readiness of the Philippine Using Different Stages Model. CCSPC R\&D Journal, 1(4).

Nento, F., Nugroho, L. E., \& Selo. (2017). Model E-Readiness Untuk Pengukuran Kesiapan Pemerintah Daerah Dalam Penerapan Smart Government: Studi Kasus Pemerintah Provinsi Gorontalo. Seminar Nasional Inovasi Dan Aplikasi Teknologi Di Industri (SENIATI), B27.1-6.

Olaolu Micheal, O., Agwu Ekwe, A., Ivande Pauline, D., \& Olaolu Tochukwu, A. (2018). Ereadiness of public extension personnel for service delivery in Benue State, Nigeria. Journal of Agricultural Extension, 22(2), 110-124. https://doi.org/10.4314/jae.v22i2.10

Sigwejo, A., \& Pather, S. (2016). A citizen-centric framework for assessing E-government effectiveness. Electronic Journal of Information Systems in Developing Countries, 74(1), 127. https://doi.org/10.1002/j.1681-4835.2016.tb00542.x

Zhang, X., Asano, Y., \& Yoshikawa, M. (2016). Mutually beneficial confluent routing. IEEE Transactions on Knowledge and Data Engineering, 28(10), 2681-2696. https://doi.org/10.1109/TKDE.2016.2590435 